Division of Geological \& Geophysical Surveys

PRELIMINARY INTERPRETIVE REPORT 2011-1

RECONNAISSANCE EVALUATION OF THE LAKE CLARK FAULT, TYONEK AREA, ALASKA

by

Rich D. Koehler and Richard D. Reger

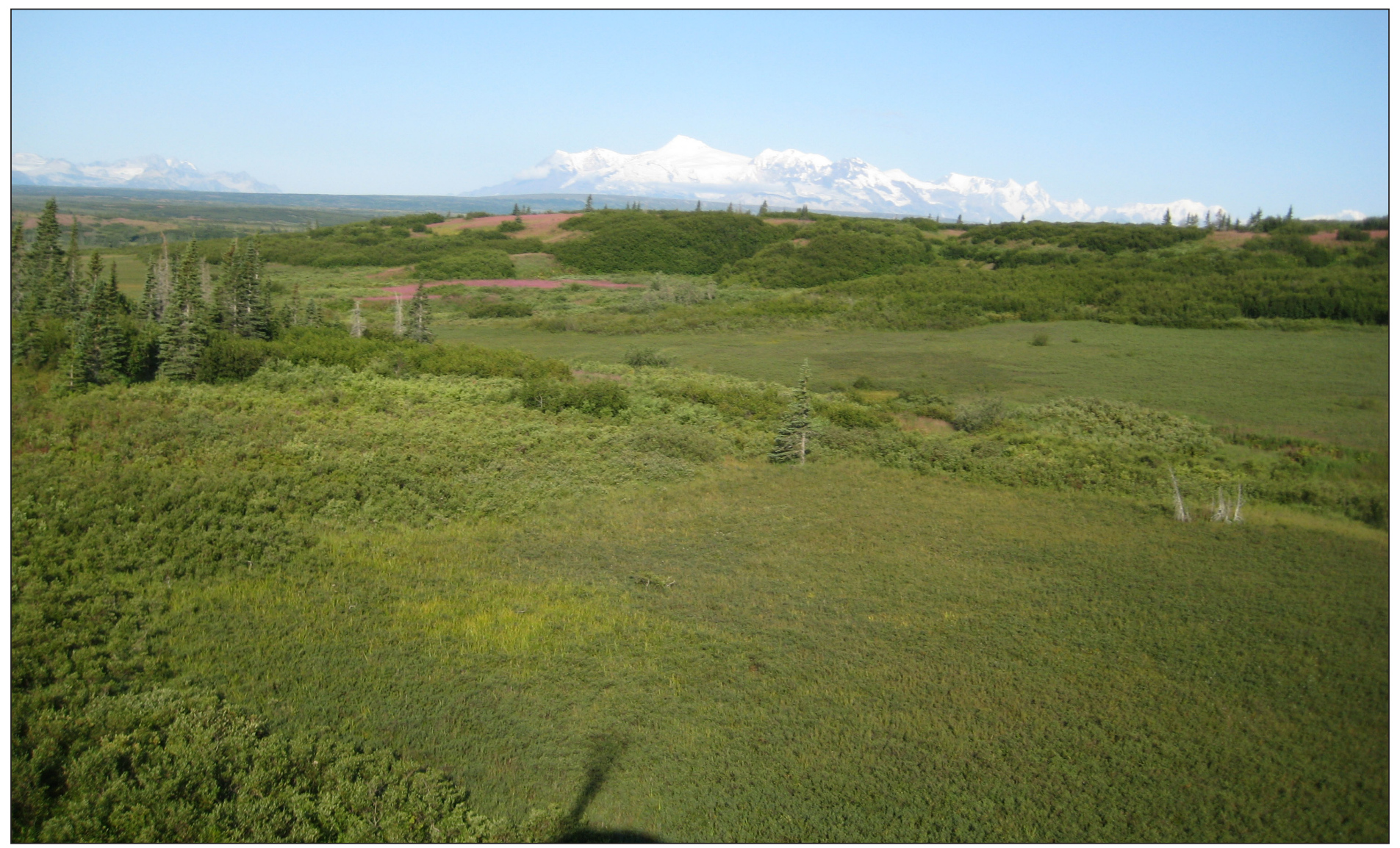

Lone Ridge, accented by pink fireweed, extends across the middleground (view to the west). Mt. Spurr and the Tordrillo Mountains are silhouetted along the skyline.

February 2011

Released by

STATE OF ALASKA

DEPARTMENT OF NATURAL RESOURCES

Division of Geological \& Geophysical Surveys 3354 College $\mathrm{Rd}$.

Fairbanks, Alaska 99709-3707

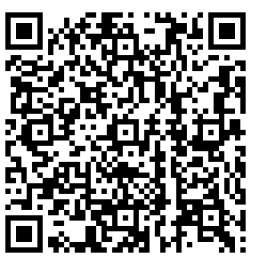





\section{CONTENTS}

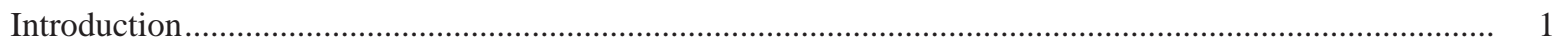

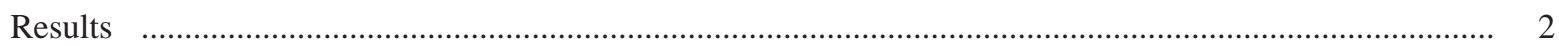

Surficial expression of the Lake Clark fault and timing of deformation.......................................... 2

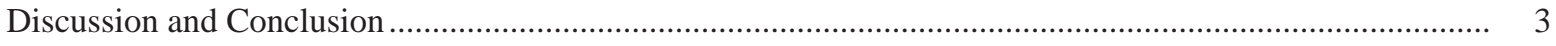

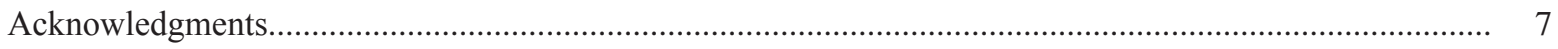

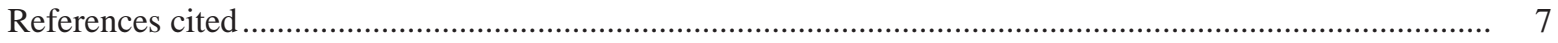

\section{FIGURES}

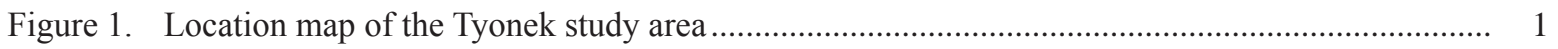

2. Preliminary surficial-geologic map of the Lone Ridge area ................................................. 3

3. Vertical false-color infrared aerial photograph of the Lone Ridge area, near Tyonek.................. 4

4. Oblique aerial photographs of the Lake Clark fault......................................................... 5

5. Stream profiles along Chuitna River and Chuit Creek..................................................... 6 



\title{
RECONNAISSANCE EVALUATION OF THE LAKE CLARK FAULT, TYONEK AREA, ALASKA
}

\author{
by
}

Rich D. Koehler ${ }^{1}$ and Richard D. Reger ${ }^{2}$

\section{INTRODUCTION}

The Lake Clark fault is a right-oblique reverse fault extending northeastward from Lake Clark in the western Alaska Range to the northern Cook Inlet forearc basin (fig. 1). Right transpressional deformation in the region is driven by collision of the Yakutat Microplate $(4.9 \mathrm{~cm} / \mathrm{yr})$ and Pacific Plate $(5.3 \mathrm{~cm} / \mathrm{yr})$ into North America (fig. 1). Previous studies of the Lake Clark fault have shown 500-1,000 m of northwest-side-up vertical displacement (Detterman and others, 1976). Estimates of post-Eocene right-lateral displacements range from $\sim 5$ to $26 \mathrm{~km}$ (Haeussler and Saltus, 2005; Plafker and others, 1975). Quaternary deformation was noted during earlier mapping efforts (Schmoll and Yehle, 1987), however, data on the timing of deformation are limited. The Castle Mountain fault may represent the northeast extent of the Lake Clark fault; it has the same strike and sense of motion. Paleoseismic

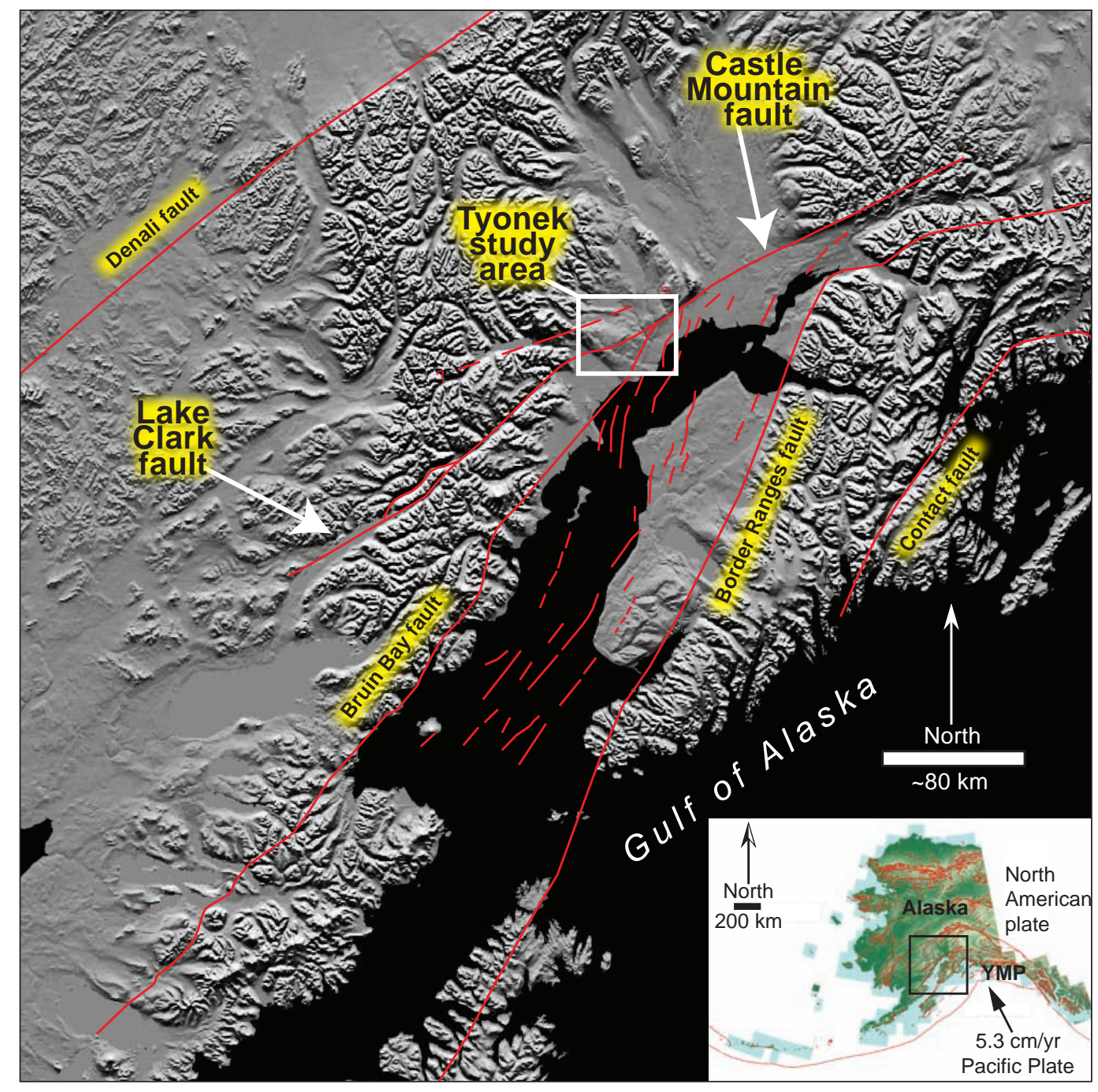

Figure 1. Location map of the Tyonek study area showing major faults in red. Area of larger, shaded digital elevation model (DEM) is indicated by the black rectangle on the inset map of Alaska. The Tyonek study area is outlined by the white rectangle on the DEM.

${ }^{1}$ Alaska Division of Geological \& Geophysical Surveys, 3354 College Rd., Fairbanks, AK 99709-3707; richard.koehler@alaska.gov ${ }^{2}$ Reger's Geologic Consulting, PO Box 3326, Soldotna, AK 99669-3326 
investigations have been conducted on the Castle Mountain fault; however, similar data for the Lake Clark fault do not exist. Thus, questions remain regarding the role of the Lake Clark fault in accommodating right-oblique strain through northwestern Cook Inlet west of the Castle Mountain fault. Prior mapping of glacial and glacioestuarine deposits in the coastal lowlands of northwestern Cook Inlet used local moraine names, complicating regional correlation. Information on the relative age of surficial deposits is a critical first step in evaluating the history of the Lake Clark fault.

The purposes of this study are (1) to map the surficial geology in the Tyonek-Capps Glacier area, northwestern Cook Inlet, as part of ongoing mapping efforts by the State of Alaska Division of Geological \& Geophysical Surveys, and (2) to perform field reconnaissance along the Lake Clark fault to document the presence or absence of Quaternary tectonic features used to evaluate the timing of deformation. The results of our efforts are incorporated into our report of surficial geology in the Tyonek STATEMAP area (Reger and others, in prep.) and will provide the basis for correlating surficial deposits in the map area with equivalent deposits elsewhere in the Cook Inlet region. We focus attention here on our field reconnaissance of the Lake Clark fault and on specific map units that place broad constraints on the recency of activity along this part of the fault. This information is important for seismic hazards assessments related to petroleum production infrastructure in the upper Cook Inlet region, including the greater Anchorage metropolitan area.

\section{RESULTS}

\section{SURFICIAL EXPRESSION OF THE LAKE CLARK FAULT AND TIMING OF DEFORMATION}

Our preliminary surficial-geologic map shows the approximate trace of the Lake Clark fault mapped by Detterman and others (1976) (fig. 2). In false-color infrared aerial photographs of the same area, we indicate relations of the fault trace to several physiographic features (fig. 3). In the Tyonek map area, we identified three ages of glacial deposits on the basis of physiographic and stratigraphic positions, surface weathering of glacial erratics, and cross-cutting relations. The relative ages of glacial deposits pertinent to our fault assessment include, from youngest to oldest: (1) Marine Isotope Stage (MIS) 2 glacial deposits of the last major (Naptowne) glaciation ( 11-30 ka), which are characterized by sharp-crested morainal morphology and fresh, well preserved erratics; (2) MIS 4 (penultimate) glacial deposits ( $60-75 \mathrm{ka})$, which are characterized by topographic positions above or beyond Naptowne glacial limits, subdued morainal morphologies, and weakly to unweathered erratics with thin to nonexistent weathering rinds; and (3) MIS 6 (pre-penultimate) glacial deposits $(\sim 130-180 \mathrm{ka})$, which are surrounded by MIS 4 glacial deposits, lack morainal expression, and have moderately weathered erratics.

At Lone Ridge, the Lake Clark fault is expressed at the surface as a $\sim 5-\mathrm{km}$-long, $\sim 20$-m-high scarp in exposed granitic bedrock (figs. 4A and 4B). To the northeast, this scarp becomes more subtle, with rounded morphology, and projects across an MIS 4 ground moraine to the oldest Naptowne lateral moraine. Surface vegetation is very dense and visibility is severely limited there (figs. 3 and 4A). Schmoll and Yehle (1987) inferred that faulting offset moraines of early Naptowne age along the northeastern side of Lone Ridge, but did not provide definitive evidence. In our opinion, the Lone Ridge fault scarp does not offset MIS 4 glacial deposits northeast of Lone Ridge, but drift of that age is likely draped across the pre-existing fault scarp. We saw no evidence for vertical or lateral offset of Naptowne glacial deposits.

Southwest of Lone Ridge and without apparent offset, the Lake Clark fault projects across MIS 4 glacial deposits, large Naptowne lateral moraines from the Chakachatna River valley, and modern alluvial deposits of the Chakachatna River (figs. 2 and 3). There, MIS 4 deposits blanket a broad, low-relief platform, the Beluga Plateau of Schmoll and others (1984) and Schmoll and Yehle (1987), with subtle north-northwest-trending drumlins and swales that likely represent paleodrainages. Two prominent drainages, the Chuitna River and Chuit Creek, are deeply incised into the platform and are not laterally displaced. Profiles constructed from topographic maps along these channels show subtle convex-up morphologies and could indicate north-side-up deformation consistent with the scarp at Lone Ridge (fig. 5). Several subtle vegetation lineaments coincide with the projection of the fault on aerial photographs, but these features were not observed during our limited helicopter reconnaissance. Crests of Naptowne lateral moraines are not laterally displaced along the projection of the fault, however we recognize that the trace of the fault may be obscured by a large landslide headscarp.

In the vicinity of Blockade Glacier southwest of the map area, the fault is expressed as a subtle sidehill bench and linear swale at a drainage divide (fig. 4C). This feature was not investigated on the ground; however, based on our helicopter survey, the fault appears to be confined to bedrock and the swale is filled by boulder debris and colluvium derived from the steep mountain front upslope. 


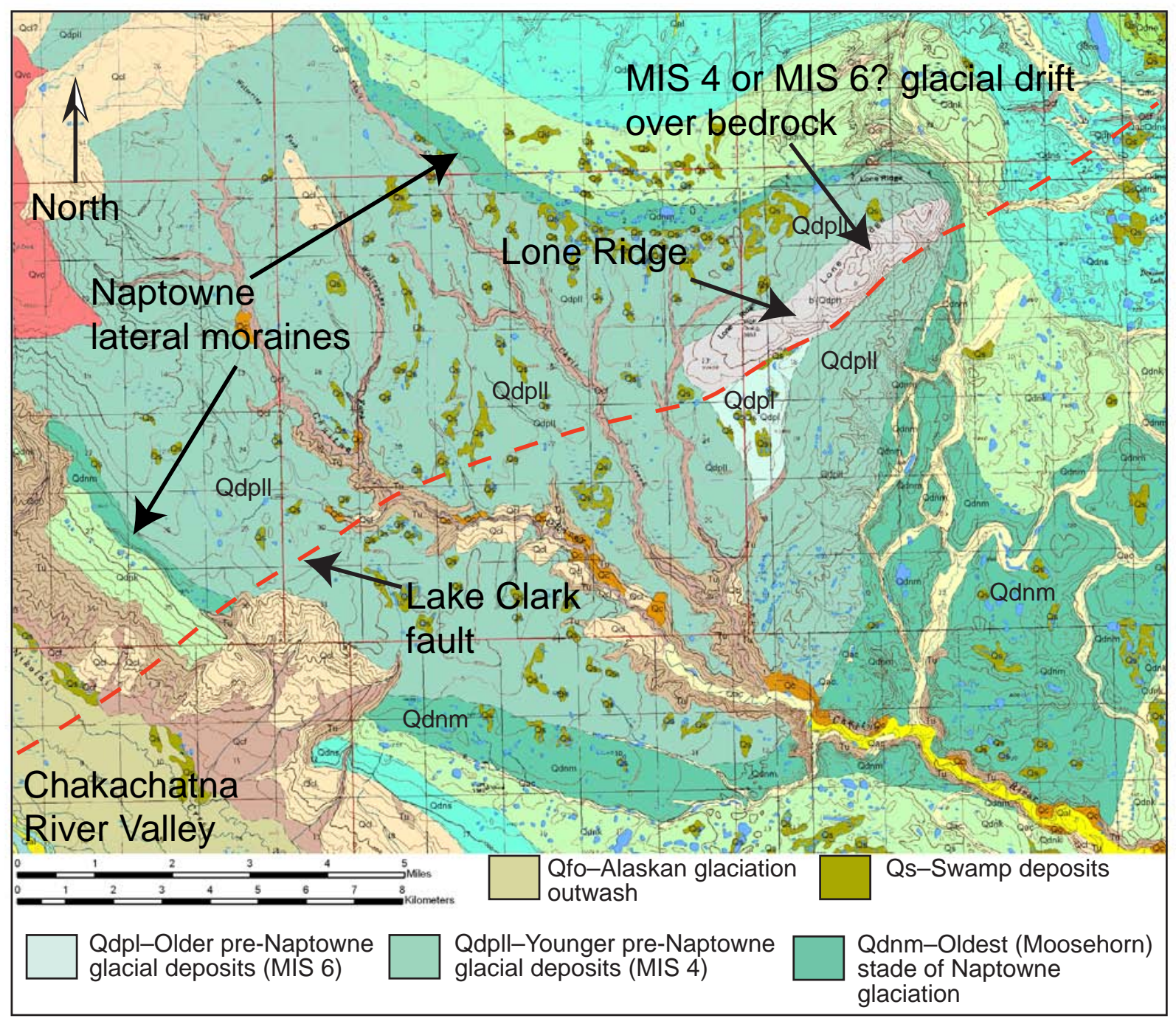

Figure 2. Preliminary surficial-geologic map of the Lone Ridge area, near Tyonek. A complete description of surficial-geologic units is included in the draft map of the Quaternary geology of the Tyonek area (Reger and others, in prep.). Unit explanations shown here are only those that are relevant to the current discussion of the Lake Clark fault.

\section{DISCUSSION AND CONCLUSION}

A reconnaissance survey of late Wisconsin and pre-late Wisconsin glacial deposits along the trace of the Lake Clark fault in the vicinity of Lone Ridge in the Tyonek area provides preliminary observations that bear on the timing of deformation and sense of motion along the fault. Based on our field observations, we believe that there is no conclusive evidence for surface displacement of MIS 2 and MIS 4 glacial deposits northeast and southwest of the prominent bedrock scarp on Lone Ridge, which is consistent with conclusions reached by Plafker and others (1975). Although no streams display horizontal offsets across the fault trend, stream profiles perpendicular to the fault have convex-up profiles, perhaps indicating that some north-side-up motion has occurred since the MIS 4 glaciation. It is possible that fault scarps related to post MIS 4 deformation have been removed or obscured by erosion. In addition, MIS 6 drift, which thinly blankets bedrock on Lone Ridge and occupies the lowland below the prominent bedrock scarp there, could be offset, leaving viable the possibility of north-side-up displacements along the Lone Ridge fault during the $\sim 130$ ky since the pre-penultimate (MIS 6) glaciation of the area.

Understanding possible kinematic linkages between the Lake Clark and Castle Mountain faults has important implications for estimating maximum earthquake rupture lengths and magnitudes in the greater Cook Inlet region. In map view, the Lake Clark fault is the southwestern extension of the Castle Mountain fault. The two faults have similar strike and sense of motion, but are characterized by different Holocene paleoseismic histories. Previous 


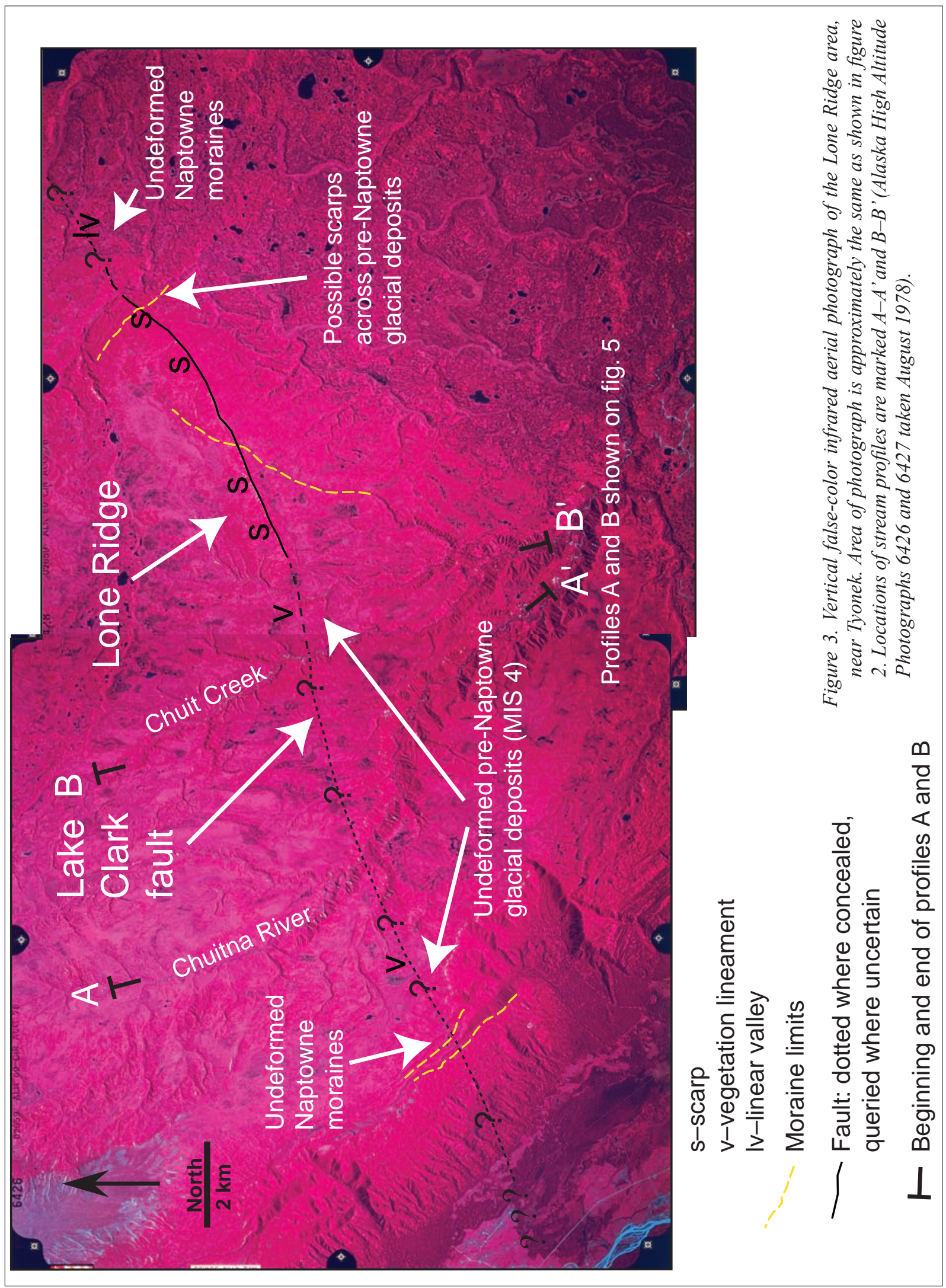




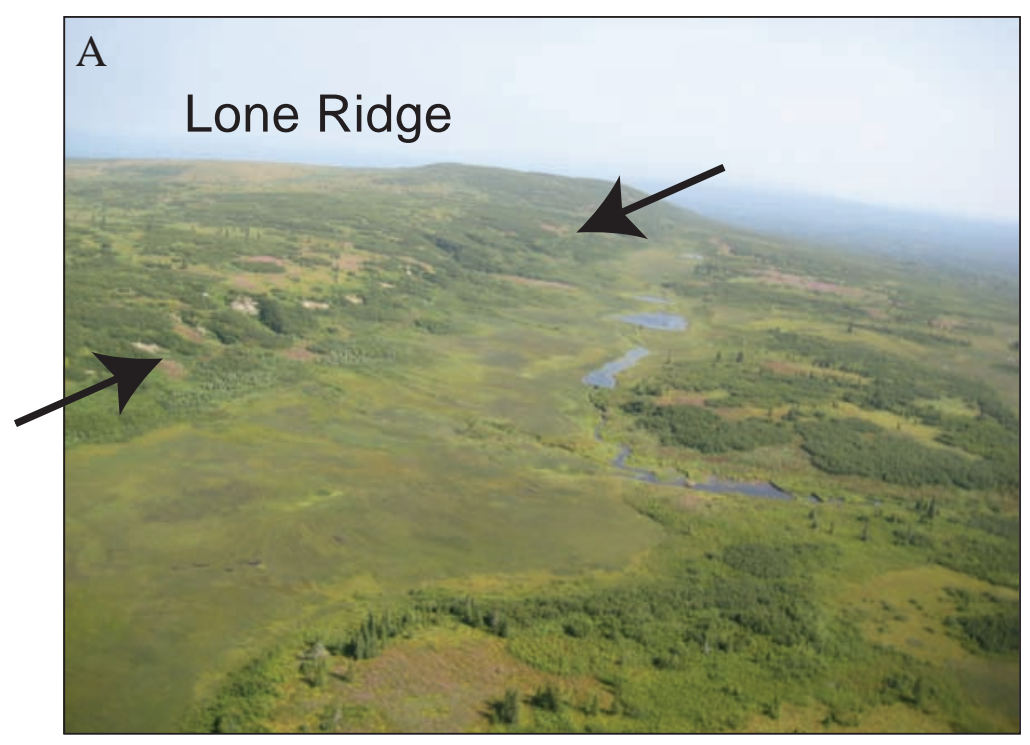

Figure 4. Oblique aerial photographs of the Lake Clark fault including (A) view to northwest of 20-m-high Lone Ridge bedrock escarpment, (B) southwest view of Lone Ridge, and (C) Lake Clark fault southwest of map area and north of Blockade Glacier. Lake Clarkfault extends between black arrows in photographs $4 A$ and $4 B$.
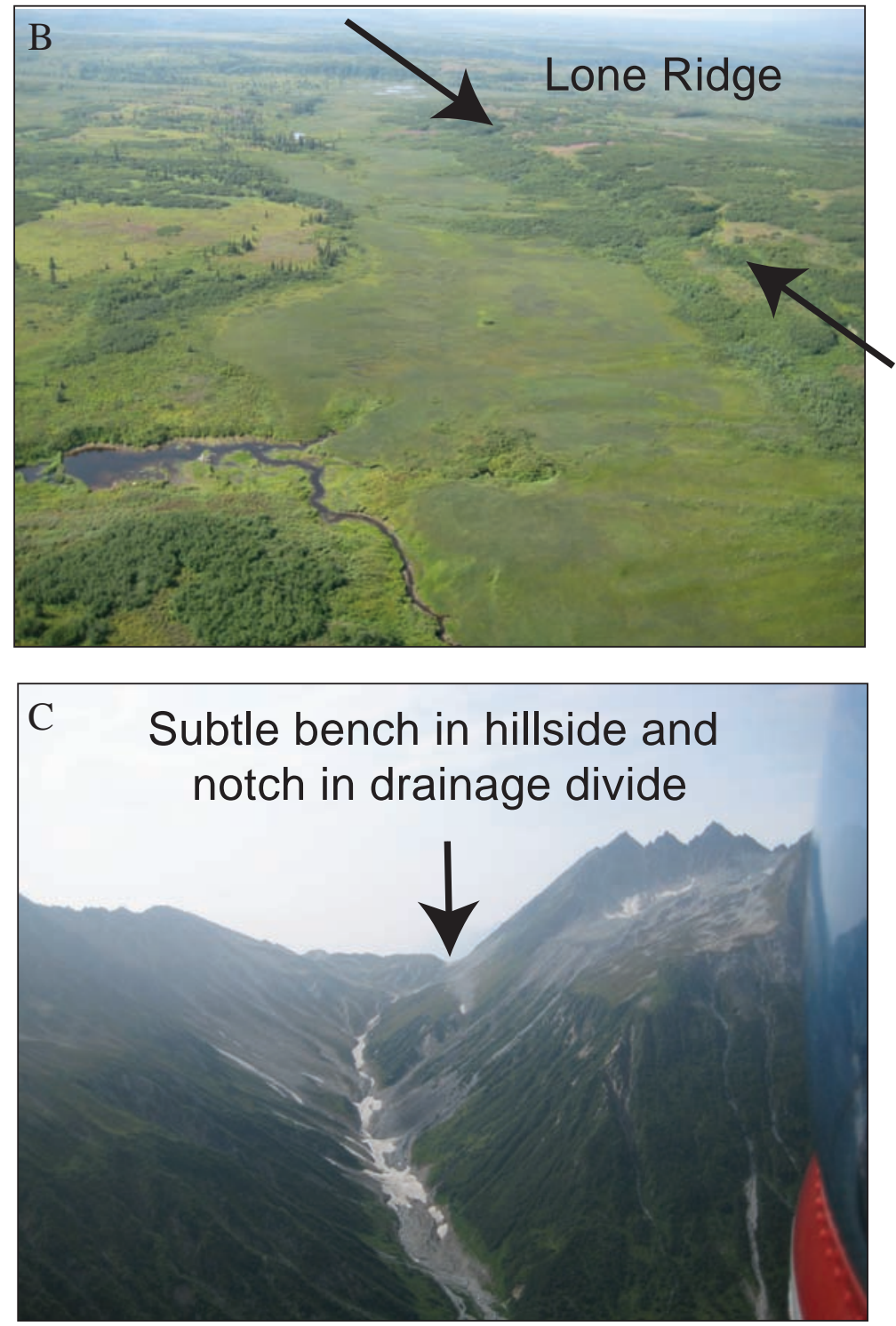
work along the Castle Mountain fault suggested the occurrence of four late Holocene surface ruptures (Haeussler and others, 2002). In contrast, our mapping indicates that the Lake Clark fault is characterized by a relatively low rate of activity and has not generated a surface-rupturing earthquake in the map area for at least the past 10-25 ky and likely the last $\sim 60$ ky since the penultimate glaciation.

Three possible explanations can account for the apparent discrepancy in relative activity between the Lake Clark and Castle Mountain faults. First, right lateral slip from the Castle Mountain fault may transition to right transpressional deformation in fault-cored folds in the Cook Inlet Basin, as originally suggested by Haeussler and others (2000). Second, distributed slip on unrecognized structures and dense vegetation that might obscure tectonic features along the Lake Clark fault could limit assessment of tectonic activity. Finally, large uncertainties in the amount of lateral slip along the Castle Mountain and Lake Clark faults may hinder comparison of their relative rates of activity. For example, estimates of the amount of late Pleistocene lateral offset along the Castle Mountain fault range from 7 to $9.1 \mathrm{~m}$ (Detterman and others., 1974) to $36 \mathrm{~m}$ (Willis and others, 2007). These offsets all postdate the recession of glacial ice from the Knik Arm of Cook Inlet 11,200-15,350 cal yr BP and the initiation of
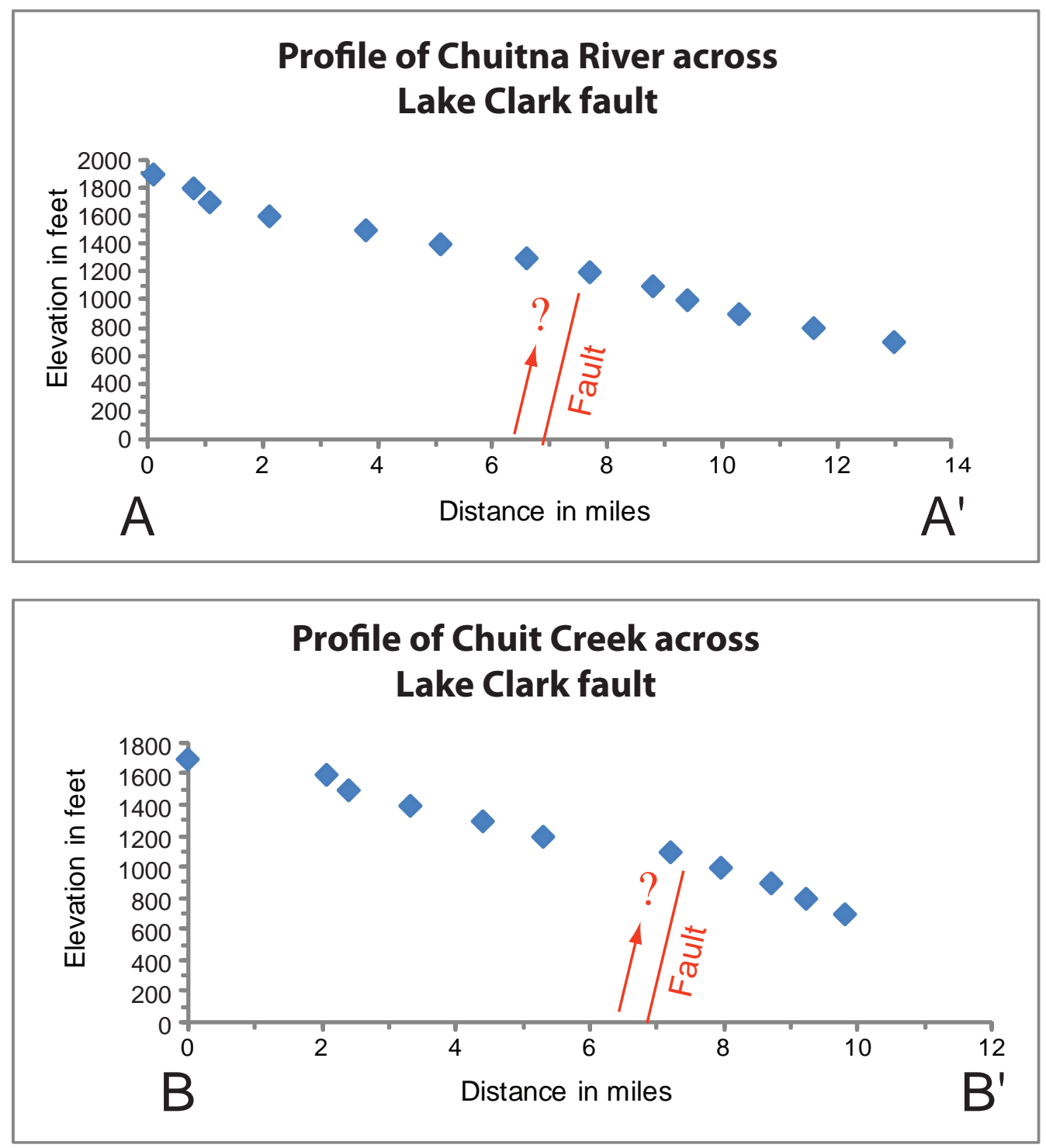

Figure 5. Stream profiles along Chuitna River and Chuit Creek, showing convex-up profiles possibly indicating Quaternary activity on the Lake Clark fault. Projection of the Lake Clark fault shown in each profile. 
outwash channel activity 11,210-13,470 cal yr BP (Reger and others, 1995), from which Willis and others (2007) estimated a late Pleistocene slip rate of 2.1-3.6 mm/yr. Using these ages and the smaller offset of Detterman and others (1974), we calculate a poorly constrained slip rate of $0.45-0.63 \mathrm{~mm} / \mathrm{yr}$ for the Castle Mountain fault, similar to the $0.5 \mathrm{~mm} / \mathrm{yr}$ estimated by Fuchs (1980) for the eastern part of the fault. For the Lake Clark fault, lateral slip estimates are limited to a $26 \mathrm{~km}$ offset of 34-39 Ma granitic plutons interpreted from aeromagnetic data (Haeussler and Saltus, 2005) and a $5 \mathrm{~km}$ offset of a 38.6 Ma granitic intrusive (Plafker and others, 1975; Reed and Lanphere, 1972). These data indicate an Eocene slip rate of $0.66-0.76 \mathrm{~mm} / \mathrm{yr}$ and $0.1 \mathrm{~mm} / \mathrm{yr}$, respectively. Thus, considering the uncertainties, the late Pleistocene slip rates on the Castle Mountain and Lake Clark faults may be similar.

The observations described above are preliminary and part of DGGS's effort to better characterize the eastern Lake Clark fault. The paleoseismic history of the western part of the Lake Clark fault remains unknown. The fault is a major topographic feature, and understanding its behavior has important implications for seismic-hazard assessments related to resource infrastructure in the Cook Inlet region and seismic safety in the greater Anchorage metropolitan area. Additional studies along the Lake Clark fault, including dating the glacial deposits, reconnaissance to the west in the Alaska Range and east in the vicinity of Mt. Susitna, and LiDAR surveys along the fault trace will serve to better characterize the fault.

\section{ACKNOWLEDGMENTS}

This research was partially funded by a U.S. Geological Survey-sponsored STATEMAP grant to the State of Alaska. Review comments by Mark Hemphill-Haley improved the final manuscript. Gratitude is extended to Garrett Speeter for assistance in the field, expert helicopter piloting by Tom "Rat" Ratledge, and the Cottonwood Lodge.

\section{REFERENCES}

Detterman, R.L., Hudson, Travis, Plafker, George, Tysdal, R.G., and Hoare, J.M., 1976, Reconnaissance geologic map along the Bruin Bay and Lake Clark faults in Kenai and Tyonek quadrangles, Alaska: U.S. Geological Survey Open File Map 76-477, 4 p., scale: 1:250,000.

Detterman, R.L., Plafker, George, Tysdal, R.G., and Pavoni, Nazario, 1974, Surface geology and Holocene breaks along the Susitna segment of the Castle Mountain fault, Alaska: U.S. Geological Survey Miscellaneous Field Studies Map MF-618, 1 plate, scale 1:24,000.

Fuchs, W.A., 1980, Tertiary tectonic history of the Castle Mountain-Caribou fault system in the Talkeetna Mountains, Alaska: Salt Lake City, University of Utah, Department of Geology and Geophysics, Ph.D. dissertation, 150 p.

Haeussler, P.J., Bruhn, R.L., and Pratt, T.L., 2000, Potential seismic hazards and tectonics of the upper Cook Inlet basin, Alaska, based on analysis of Pliocene and younger deformation: Geological Society of America Bulletin, v. 112, no. 9, p. 1,414-1,429.

Haeussler, P.J., Best, T.C., and Waythomas, C.F., 2002, Paleoseismology at high latitudes; Seismic disturbance of upper Quaternary deposits along the Castle Mountain fault near Houston, Alaska: Geological Society of America Bulletin, v. 114, no. 10, p. 1,296-1,310.

Haeussler, P.J., and Saltus, R.W., 2005, 26 km of offset on the Lake Clark fault since late Eocene time, in Haeussler, P.J., and Galloway, J.P., eds., Studies by the U.S. Geological Survey in Alaska, 2004: U.S. Geological Survey Professional Paper 1709-A, 4 p.

Plafker, George, Detterman, R.L., and Hudson, Travis, 1975, New data on the displacement history of the Lake Clark fault, in Yount, M.E., ed., United States Geological Survey Alaska Program, 1975: U.S. Geological Survey Circular 722, p. 44-45.

Reed, B. L., and Lanphere, M.A., 1972, Generalized geologic map of the Alaska-Aleutian Range batholith showing potassium-argon ages of the plutonic rocks: U.S. Geological Survey Miscellaneous Field Studies Map MF-372, 2 plates, scale 1:1,000,000.

Reger, R.D., Combellick, R.A., and Brigham-Grette, Julie, 1995, Late-Wisconsin events in the upper Cook Inlet region, southcentral Alaska, in Combellick, R.A., and Tannian, Fran, eds., Short Notes on Alaska Geology 1995: Alaska Division of Geological \& Geophysical Surveys Professional Report 117, p. 33-45.

Reger, R.D., Stevens, D.S.P, and Koehler, R.D., in prep., Surficial geology of the Tyonek STATEMAP area, south-central Tyonek Quadrangle, Alaska: Alaska Division of Geological \& Geophysical Surveys Report of Investigations, booklet, 1 sheet, scale 1:63,360. 
Schmoll, H.R., and Yehle, L.A., 1987, Surficial geologic map of the northwestern quarter of the Tyonek A-4 quadrangle, south-central Alaska: U.S. Geological Survey Miscellaneous Field Studies Map MF-1934, 1 sheet, scale $1: 31,680$.

Schmoll, H.R., Yehle, L.A., Gardner, C.A., and Odum, J.K., 1984, Guide to surficial geology and stratigraphy in the upper Cook Inlet basin [prepared for the $80^{\text {th }}$ annual meeting of the Cordilleran Section, Geological Society of America]: Anchorage, Alaska Geological Society, 89 p.

Willis, J.B., Haeussler, P.J., Bruhn, R.L., and Willis, G.C., 2007, Holocene slip rate for the western segment of the Castle Mountain fault, Alaska: Bulletin of the Seismological Society of America, v. 97, no. 3, p. 1,019-1,024. 